\title{
Do sukuk ratings non-contingently affect stock returns? Evidence from Indonesia and Malaysia
}

\author{
Ibnu Qizam
}

\begin{abstract}
A B S TR A C T
Objective: The objective of the article is to investigate two issues. First, whether the Islamic bond (sukuk) ratings are the key determinant in affecting stock returns and, second, whether firm-characteristic variables moderate the sukuk ratings effect on stock returns.
\end{abstract}

Research Design \& Methods: This study applied the panel estimated generalized least squares (EGLS) regression for two samples (from Indonesia and Malaysia) spanning two years, 2015-2016, for all variables, except for the intrinsic-value variable which spanned eight years, 2009-2016.

Findings: The results show that the direct and positive effect of sukuk ratings on stock returns are significantly present in Malaysia but not in Indonesia, while the positive and significant moderating effects of firm-characteristic variables - especially leverage and intrinsic value of the firm - are more pronounced in the positive sukuk rating-stock return relationship in Indonesia than in Malaysia.

Implications \& Recommendations: The types of firm-characteristic variables involved in determining the effect of sukuk ratings on stock returns depend on the country's characteristics. As a result, adopting sukuk ratings to determine stock returns is not constant but, instead, it is contingent - to an extent - on other variables: firm-characteristic variables. These results suggest that still many factors should be explored so as to reach a better judgment on the quality of credit, including sukuk.

Contribution \& Value Added: While most previous studies employed the event-study method and did not specifically consider firm-characteristic effects on analysing the relationship between sukuk ratings and stock returns, this study sought to reveal whether sukuk ratings are the key determinant in affecting prices (or stock returns), and the extent to which firm-characteristic variables moderate the relationship between sukuk ratings and stock returns.

\begin{tabular}{llll}
\hline $\begin{array}{l}\text { Article type: } \\
\text { Keywords: }\end{array}$ & research article & \\
JEL codes: & sukuk ratings; credit ratings; stock returns; firm characteristics & \\
\hline \multicolumn{2}{c}{ Received: 2 June 2020} & Revised: 4 October 2020 & Accepted: 4 November 2020 \\
\hline
\end{tabular}

\section{Suggested citation:}

Qizam, I. (2021). Do sukuk ratings non-contingently affect stock returns? Evidence from Indonesia and Malaysia. Entrepreneurial Business and Economics Review, 9(1), 137-153. https://doi.org/10.15678/EBER.2021.090109

\section{INTRODUCTION}

This study aims to examine whether sukuk ratings can be the key determinant in affecting stock returns directly, which is not contingent on firm-characteristic variables, or whether the sukuk ratings effect on stock returns is subject to the varying firm-characteristic factors: leverage and firm value. This issue arises from the basic assumption that the significant role of sukuk ratings, including credit ratings, is an intermediary providing information through which are conveyed some signals of creditworthiness and sustainability, commonly sourced from an assessment to a firm's fundamental analysis, e.g. expected future cash flows, firm value, leverage level, default-risk profile, market competitiveness, or governance (see Muhamad Sori, Mohamad, \& Al Homsi, 2019). Therefore, sukuk ratings can reduce information asymmetry between investors and managers, so sukuk rating changes will be efficiently reflected in stock prices. 
As defined by most scholars, sukuk are sharia-compliant debt instruments or non-interest-based securities with the ownership of an underlying asset (Bhatti, 2007) or Islamic bonds (Alam, Hassan, \& Haque, 2013). The main characteristic of sukuk that distinguishes it from conventional bonds is the underlying asset, a reference of issuing debt whose value is not allowed to exceed the value of the asset. Thus, as a risky instrument, sukuk is also an instrument of debt-based financing that has certain restrictions which, if uncontrolled, will endanger a firm. Due to the sukuk characteristics, the quality and credibility of the sukuk owned by a firm can also be assessed. Since a 'good' or 'bad' rating rendered by a credit-rating agency is usually attributed to the assessment of a historical record on sukuk issuers' credibility in their credit, repayment, underlying assets, and whole business performance (Arundina, Omar, \& Kartiwi, 2015), we may argue that stock returns respond to credit or sukuk ratings while also retaining other firm-characteristic factors to be considered.

Until recently, studies regarding the effects of conventional credit and sukuk ratings on returns show that, among other things, credit rating changes show a reaction among investors, mostly indicated by stock price reaction irrespective of symmetric (Muhamad Sori et al., 2019) or asymmetric stock price changes for sukuk; i.e. a bond or sukuk that tends to emphasise more downward than upward credit-rating changes (Bissoondoyal-Bheenick \& Brooks, 2015; Freitas \& Minardi, 2013). Most scholars support of these findings. Among others, Ng and Ariff (2019) conventionally find the significant credit rating change effect on sharia-compliant stock prices. Ab Hamid, Zakaria, and Ab Aziz (2014) reveal the significant effect of sukuk ratings on firm performance. Paltrinieri, Hassan, Bahoo, and Khan (2019) find a significant sukuk-stock market behaviour relationship. Abd Rahim and Ahmad (2016) document a positive and significant asymmetrical reaction to sukuk issuance in which the announcement of 'high-quality,' 'excellent,' and 'good' of sukuk ratings receives positive responses, while 'medium,' 'questionable,' and 'weak' ratings show negative reactions. Khartabiel, Abu-Alkheil, Tunku Ahmad, and Khan (2020) find that in the post-crisis period, market reaction to sukuk is positive and significant, while insignificant for conventional bonds (see also Mohamed, Yahya, \& Ishak, 2017).

However, other studies find different results, e.g. Alam et al. (2013) find that markets reacted negatively to sukuk announcements before and during the 2007 global financial crisis. Godlewski, Turk-Ariss, and Weill (2010) find no significant stock market reaction to conventional bond announcements, which reacted negatively to the issuance of sukuk. Furthermore, Godlewski, Turk-Ariss, and Weill (2013) find evidence that the stock market is neutral to conventional bond announcements but reacts negatively to sukuk announcements instead. Hassan, Paltrinieri, Dreassi, Miani, and Sclip (2018) find that sukuk and conventional bonds at the investment-grade level had lower volatility reactions to market shocks and higher persistence, while Khartabiel et al. (2020) suggest that there was no market reaction to the announcement of sukuk and conventional bonds in the pre-crisis period of the 2008 global financial crisis and during the crisis period, as the market reacted negatively significantly to both groups.

Given these studies, we may conclude that the phenomena of sukuk and sukuk ratings still show different reaction from their users and investors. Moreover, previous studies never explicitly review the issue of whether sukuk ratings can be used as a key determinant in pricing - mostly considered by investors - or whether the sukuk ratings as a determinant of prices is influenced by other variables. These two issues remain understudied in previous studies. In theory, like conventional credit ratings, sukuk ratings are not only built by financial and accounting data but also by other relevant information (see Hand, Holthausen, \& Leftwich, 1992; Grier \& Katz, 1976). This is also stated explicitly by Moody's (1995) who argues that the credit rating development process is indeed subjective because it refers to assessing the ability of future entities, which involves many unique factors related to certain industries and debt issuers so that if there is an attempt to simplify this process with a formula, it will be misleading and will result in serious mistakes. Hence, sukuk rating practices - including conventional credit ratings - are always dynamic under scientific scrutiny. Some results support the market reaction when the sukuk was announced, but other do not confirm such an investors' reaction. The reasons why the results were dynamic may also be attributed to many factors, like firm-characteristic factors.

Furthermore, to the best of my knowledge, most previous studies focus on employing the eventstudy method, but not to specifically consider whether sukuk ratings are the key determinant in affecting stock returns disregarding firm-characteristic variables or whether the relationship be- 
tween sukuk ratings and stock returns is contingent on firm-characteristic variables. As such, this research seeks to reveal whether sukuk ratings are the key determinant in affecting stock prices (or stock returns), and the extent to which firm-characteristic variables moderate the relationship between sukuk ratings and stock returns.

To answer these research issues, the stock markets from two countries - Indonesia and Malaysia - were used as samples in this study due to their dominance of the global sukuk market. The global sukuk market share for Malaysia and Indonesia is $68.06 \%(60.84 \%+7.225 \%)$ or approximately 749613 million USD (670 121 million USD + 79492 million USD) (IIFM, 2019). Because of the dominance of these two countries - which account for nearly $70 \%$ out of the global sukuk market - Indonesia and Malaysia as the samples in this study should be considered reasonable.

The rest of this paper will present a literature review and hypothesis development, describe materials and methods, provide results and discussion, and draw a conclusion and implications.

\section{LITERATURE REVIEW AND HYPOTHESES DEVELOPMENT}

As conclusively stated by many scholars, sukuk functions as a debt-based instrument with an underlying asset, and it enjoys a specific and complicated assessment. Due to the complexities and potential conflicts of interest when the assessment is conducted internally by the issuing firm or externally by investors, the quality of the sukuk is delivered for assessment by rating agencies who have the ability and expertise and who are considered to be independent and objective. This means the big three rating agencies - Moody's, Fitch, and Standard \& Poor's - and smaller rating agencies on the country level. For example, at the level of the Association of Southeast Asian Nations (ASEAN), agencies that usually assign rating attributes are Perseroan Terbatas Pemeringkat Efek Indonesia (PT. PEFINDO) in Indonesia, Rating Agency Malaysia (RAM) services and Malaysian Rating Corporation Berhad (MARC) in Malaysia, Universal Ratings (RTS Ratings Pte Ltd.) in Singapore, Thai Rating and Information Services Co. Ltd. (TRIS) in Thailand, and Philippine Rating Services (Phil Ratings) in the Philippines.

Since Blume, Lim, and Mackinlay (1998) mapped credit-rating studies from the conventional literature viewpoint, the literature on sukuk ratings has been extensively growing. Zulkhibri (2015) identifies three groups of sukuk studies. The first group indicates sukuk's qualitative descriptions like the extent of figh (jurisprudence) explanation related to sukuk, the differences in nature of sukuk from conventional bonds, and the differences in characteristics of sukuk-risk indicators, the mechanism of sukuk, and its compliance with the norms of Islamic jurisprudence; the prime components of sukuk from the Iranian Syiah fiqh viewpoint (see e.g. Rohim \& Shereeza, 2013; Usmani, 2008; Kordvani, 2009). In the second group - as discussed in conventional credit rating studies - sukuk-related studies are associated with the investigation of the determinants of sukuk, i.e. the difference between sukuk and Eurobonds, the macroeconomic impact on sukuk issuance, and how the financial crisis affects sukuk market development (see e.g. Ariff \& Safari, 2015; Ahmad, Daud, \& Kefelia, 2012; Said \& Grassa, 2013).

Furthermore, sukuk issuance that has declined in recent years - attributed to the financial crisis also results in various findings of sukuk rating studies; many new determinants are then considered in bond and sukuk rating policies. Hand et al. (1992) and Grier and Katz (1976) suggest that financial statements are considered inadequate in providing explanations related to rating standards (see also Arundina et al., 2015; Blume et al., 1998). This is also in line with Moody's statement that credit ratings have more characteristics than the description of contents of financial statements, involving so many factors unique to particular industries, issuers, and countries. As a result, no formulaic methodology can be applied (Moody's Credit Ratings \& Research, Moody's Investors Service, 1995, p. 14).

The third group deals with the extent to which information on sukuk can be utilized by stakeholders - primarily investors - or tests the extent to which sukuk issuance is a determinant in prices or wealth for investors or other firm performance, e.g. insolvency risk. Sukuk-related studies in this domain are not diverse: stock price reaction to credit/sukuk rating changes or information content of sukuk issuance on abnormal return either in the crisis period or non-crisis period and sukuk rating impact on firm performance (see e.g. Ng \& Ariff, 2019; Alam et al., 2013; Abd Rahim \& Ahmad, 2016; Hassan et al., 
2018; Khartabiel et al., 2020; Mohamed et al., 2017; Smaoui, Mimouni, \& Temimi, 2019; Ab Hamid et al., 2014; Godlewski et al., 2010). Hence, the first hypothesis is as follows:

H1: Sukuk ratings positively impact stock returns.

Paltrinieri et al. (2019) group sukuk literature into three research themes: sukuk overview and growth, sukuk and finance theories, and sukuk and stock market behaviour. The first theme addresses the definition of sukuk (see e.g. Hassan, Aliyu, Paltrinieri, \& Khan, 2019; Ahmed \& Elsayed, 2019; Asutay \& Hakim, 2018; Smaoui \& Khawaja, 2017; and many others), the classification of sukuk as asset-backed and asset-based sukuk (see Ahmed \& Elsayed, 2019; Naifar \& Hammoudeh, 2016), and the recent growth of sukuk (Smaoui \& Nechi, 2017).

From the major finance theories perspective (the second group), sukuk literature conclusively addresses beneficial effects from diversifying portfolio, choosing sukuk over conventional bonds, and investors' religiosity (Alam et al., 2013; Naifar \& Hammoudeh, 2016; Nagano, 2017; Mohamed et al., 2017; Azmat, Skully, \& Brown, 2014; Klein, Turk, \& Weill, 2017; Shafron, 2018). Meanwhile, for the third group, sukuk is mostly linked to how much the stock market responds to sukuk and bonds (Godlewski et al., 2013; Fauzi, Foo, \& Basyith, 2017), how sukuk and bonds show inter-temporally their co-movements and linkages (Aloui, Hammoudeh, \& Hamida 2015a; Alaoui, Dewandaru, Rosly, \& Masih, 2015; Sclip, Dreassi, Miani, \& Paltrinieri, 2016), what are the changes of sukuk structure due to the global financial crisis and other influential economic events, how different price regimes lead to the different correlation between the stock market and sukuk (Naifar, Hammoudeh, \& Al dohaimanae, 2016; Aloui, Hammoudeh, \& Hamida, 2015b, 2015c), and how interest rate impacts the sukuk market (Akhtar, Akhtar, Jahromi, \& John, 2017).

The above literature review from either Zulkhibri (2015) or Paltrinieri et al. (2019) suggests that their studies highlight the same angle from one of the three themes they identified. It is empirical evidence that stock market reaction, stock abnormal returns to sukuk issuance, or sukuk rating changes occur even though its effects are different and contingent. As such, its effects are not constant and may vary with changes, e.g. in the quality of sukuk ratings (Abd Rahim \& Ahmad, 2016). Furthermore, sukuk ratings are contingent on the specific characteristics of Islamic bonds (Azmat et al., 2014), along with macroeconomic and market conditions (Hassan et al., 2019). Besides, sukuk ratings are influenced by the different settings of crisis vs non-crisis period (Khartabiel et al., 2020), by the different absorption process levels of the received information from sukuk announcement (Mohamed et al., 2017), and by different insolvency risk levels and the size of issuing firms, including financial institutions (Islamic banks) (Smaoui et al., 2019).

Extant literature conceptually shows that a moderating variable plays a role in influencing the nature - i.e. the magnitude, strength, or direction - of the effect on the relationship between an independent variable and a dependent variable (Wu \& Zumbo, 2008; Aguinis, Edwards, \& Bradley, 2017). Thus, this insight shows that a moderating variable depends on the conditions under which an antecedent affects an outcome. The effect of independent variables on a dependent variable is generally contingent on many factors. Given the contingency effect of other factors on the sukuk rating-capital market behaviour relationship, as mentioned above, and the existence of various determinants of credit ratings - i.e. firm-characteristic variables, including leverage, profitability, size, growth, and financial market performance (Murcia, Murcia, Rover, \& Borba, 2014; Elhaj, Muhamed, \& Ramli, 2015) - firm-characteristic variables also presumably serve as a moderating role in influencing the positive relationship between sukuk ratings and stock returns. Thus, the following hypothesis is worth testing:

H2a: Firm-characteristic variables (i.e. leverage) positively moderate the relationship between sukuk ratings and stock returns.

H2b: Firm-characteristic variables (i.e. firm value) positively moderate the relationship between sukuk ratings and stock returns. 


\section{RESEARCH METHODOLOGY}

\section{Population, sample, and variables}

This study applied the panel estimated generalized least squares (EGLS) regression to two samples (Indonesia and Malaysia) purposively taken from two sets of the population of financial and nonfinancial firms listed on the Indonesia Stock Exchange (IDX) consisting of eight industries (61 sukukissuing firms): miscellaneous industry (5), trade, service, and investments (8), mining (5), property, real estate, building construction (10), consumer good industry (4), finance (25), infrastructure, utility and transportation (3), basic industry and chemical (1). Moreover, they were taken from the Kuala Lumpur Stock Exchange (KLSE) covering eleven industries (30 sukuk-issuing firms): among others, financial services (4), industrial products and services (5), energy (3), construction (2), real estate investment trusts (3), plantation (2), property (2), technology (1), telecommunications and media (3), transportation and logistics (3), utilities (2). To determine the dependent variable - i.e. stock returns (RET) - the data were taken from the annualised data returns for the 2015-2016 period from sukuk-issuing firms while independent variables - consisting of sukuk ratings (SRAT) - stemmed from sukuk rating agencies, i.e. PT. PEFINDO for the Indonesian samples and RAM Rating Services Berhad for the Malaysian samples available online on their official websites.

Referring to Ayturk, Asutay, and Aksak (2017), credit rating scales were transformed into a continuous score index evenly spanning from the highest scale (indexed as 1) to the lowest scale (indexed as 1 divided by the total number of the specific credit rating agency's scales). In PT. PEFINDO, for example, there are eighteen levels of credit-rating scales from 'idAAA' to 'idD'. Since each range from a higher scale to a lower scale is approximately 0.056 (i.e. 1 divided by 18), the first score index for the highest scale (idAAA) is equal to 1 , while the second scale (idAA+) will be 0.944 ( 1 minus 0.056 ), and so on until the end $\left(18^{\text {th }}\right)$ level of the credit-rating scales (idD), indexed as 0.056 . When a firm is assigned with more than one sukuk-rating scale due to different sukuk types, the score index is the average score index of combined sukuk-rating scales. Henceforth, firm-characteristic variables were proxied by leverage (LEV) and firm-value variables (VAL) consisting of return on investment (ROI), intrinsic value (IVAL), and the market value of the firm measured by Tobin's $Q$ (TBNQ), interchangeably applied depending on the relative importance of the tests (Haj-Salem, Damak Ayadi, \& Hussainey, 2020), while the natural logarithm of total assets (In_SIZE) was used to control for firm-size effect, as usually adopted by many researchers (see Dang, Li, \& Yang, 2018).

While these variables involve some common proxies such as RET, ROI, LEV, In_SIZE, SRAT, and other firm value proxies, IVAL and TBNQ are measured for specific purposes. The continuous measurement of sukuk ratings is intended to consider more the whole information of their variance explained rather than categorical-scale measurement that was mostly applied by previous studies. Next, a firm's value proxied by IVAL reflects a firm's intrinsic value that the market does not necessarily reflect in stock prices. On the one hand, the advantage of using IVAL is that it more comprehensively represents all the tangible and intangible assets of the firm in the long run, based on fundamental analysis, rather than in the short run as reflected in stock prices (Lin \& Sung, 2014). On the other hand, a firm's value proxied by TBNQ better reflects the market price of the firm in the short run. Tobin's $Q$ that indicates more than 1 means 'overvalued' while TBNQ that lies between 0 and 1 points to 'undervalued;' its advantage is the value being more relevant in the short-run analysis (Haj-Salem et al., 2020). As a result, the specific measurement of some variables (i.e. SRAT and TBNQ vs IVAL) included in the testing models was also a gap to be filled with the findings of this study, which was different from previous studies. Then, the data were sourced from Thompson Reuters Datastream for the 2015-2016 period, while a firm-value variable proxied by IVAL was generated from a longer data series, i.e. 2009-2016. The source, description, and measurement of all the variables in detail are depicted in Table 1.

\section{Empirical Models}

The empirical models are divided into two, i.e. Model 1 includes RET (a dependent variable), SRAT, and firm-characteristic variables proxied by LEV and VAL (a firm's value) that consist of ROI, IVAL, 
TBNQ (independent variables), and Ln_SIZE (control variable). Model 2 contains the same variables as Model 1 with the addition of interaction terms between SRAT and all firm-characteristic variables, i.e. the SRAT-ROI, SRAT-LEV, SRAT-IVAL, and SRAT-TBNQ interactions as the independent variables to reflect the moderating effects of ROI, LEV, IVAL, and TBNQ on the SRAT-RET relationship. The empirical models 1 and 2 appear as follows:

$$
\begin{gathered}
R E T_{i, t}=\alpha_{0}+\alpha_{1} S R A T_{i, t}+\alpha_{2} L E V_{i, t}+\sum \alpha_{3} V A L_{i, t}+\alpha_{4} L n_{-} S I Z E_{i, t}+\omega_{i, t} \\
R E T_{i, t}=\beta_{0}+\beta_{1} S R A T_{i, t}+\beta_{2} L E V_{i, t}+\sum \beta_{3} V A L_{i, t}+\beta_{4} S R A T_{i, t} * L E V_{i, t}+\sum \beta_{5} S R A T_{i, t} \\
* V A L_{i, t}+\beta_{6} L n_{-} S I Z E_{i, t}+\varepsilon_{i, t}
\end{gathered}
$$

\begin{tabular}{|c|c|c|}
\hline Variables & Description and measurement & Source \\
\hline$R E T_{\text {it }}-$ & Average annualised stock returns for the $2015-2016$ period. & $\begin{array}{l}\text { Thompson Reuters } \\
\text { Datastream }\end{array}$ \\
\hline$S R A T_{i t}-$ & $\begin{array}{l}\text { Sukuk ratings were rendered by a specific rating agency (PT. PEFINDO } \\
\text { for Indonesia sample, and RAM Rating Services Berhad for Malaysia) on } \\
\text { the sukuk-issuing firms from } 2015 \text { to } 2016 \text {. The qualitative sukuk ratings } \\
\text { are then converted into continuous metrics calculated by referring to } \\
\text { Ayturk et al. (2017). For the Indonesian sample, the sukuk ratings range } \\
\text { from idAAA (a score index } 1 \text { ) to } 1 \mathrm{dD} \text { (a score index }=0.056 \text { ), plus addi- } \\
\text { tional mixed ratings, while for the Malaysian sample, the sukuk ratings } \\
\text { span from AAA (a score index } 1 \text { ) to D (a score index }=0.05 \text { ), plus addi- } \\
\text { tional mixed ratings (see the detailed distribution in Table } 2 \text { ). }\end{array}$ & $\begin{array}{l}\text { The Indonesian Sample: PT. } \\
\text { PEFINDO (Pemeringkat Efek } \\
\text { Indonesia) } \\
\text { (https://www.pe- } \\
\text { findo.com); } \\
\text { The Malaysian sample: } \\
\text { RAM (Rating Agency Malay- } \\
\text { sia) Rating Services Berhad } \\
\text { (https://www.ram.com.my) }\end{array}$ \\
\hline$L E V_{i t}-$ & $\begin{array}{l}\text { Firm leverage and leverage (LEV) calculated by the ratio of debt di- } \\
\text { vided by total assets for the 2015-2016 period. }\end{array}$ & $\begin{array}{l}\text { Thompson Reuters } \\
\text { Datastream }\end{array}$ \\
\hline \multirow[t]{3}{*}{$V A L_{i t}-$} & $\begin{array}{l}\text { Firm value: the first one was proxied by the ratio of earnings divided } \\
\text { by total assets (return on assets or ROI); }\end{array}$ & $\begin{array}{l}\text { Thompson Reuters } \\
\text { Datastream }\end{array}$ \\
\hline & $\begin{array}{l}\text { The second one was proxied by the value of Tobin's Q (TBNQ), which } \\
\text { is the value of the equity market capitalization plus total assets minus } \\
\text { the book value of equity, all of which are then divided by total assets; }\end{array}$ & $\begin{array}{l}\text { Thompson Reuters } \\
\text { Datastream }\end{array}$ \\
\hline & $\begin{array}{l}\text { The third one was represented by intrinsic value (IVAL) that was de- } \\
\text { termined by adopting the Graham formula (Lin \& Sung, 2014), as ap- } \\
\text { plied by Qizam and Fong (2019). } \\
\qquad I V A L=\frac{(E P S *(8.5+2 g) * 4.4)}{Y} \\
\text { in which IVAL represents the next seven-year expected value of } \\
\text { growth; earning per share (EPS) is the last earnings per share for a firm; } \\
8.5 \text { is a price-to-earning (PE) base for a non-growth firm; } g \text { is the rate } \\
\text { of a reasonably expected seven-year growth; } 4.4 \text { is the average yield } \\
\text { of } 20 \text {-year AAA corporate bonds (US) in } 1962 \text { (instead of } 4.4 \text {, the cen- } \\
\text { tral bank interest rates of each country are adopted attributable to the } \\
\text { application of risk-free rates for the two samples); Y is the current yield } \\
\text { on AAA corporate bonds. Meanwhile, the calculation of intrinsic value } \\
\text { (IVAL) of firm } i \text { in year } t \text { itself necessitates an array of lagged EPS to } \\
\text { arrive at the expected EPS growth. In this regard, two-year observa- } \\
\text { tions of the firm's intrinsic value (IVAL), 2015-2016, are determined, } \\
\text { each of which was built from a long array of lagged seven-year obser- } \\
\text { vations, i.e. a 2009-2015 EPS-growth data series for IVAL of } 2015 \text { and a } \\
2010-2015 \text { EPS-growth data series for IVAL of } 2016 \text {. }\end{array}$ & $\begin{array}{l}\text { Thompson Reuters } \\
\text { Datastream }\end{array}$ \\
\hline$L n_{-} S I Z E_{i t}-$ & $\begin{array}{l}\text { Control variable, proxied by the total asset (in the natural logarithm } \\
\text { of total assets) for the } 2015-2016 \text { period. }\end{array}$ & \\
\hline$\omega i, t ; \varepsilon i, t$ & Error terms. & \\
\hline
\end{tabular}

Table 1. Source, description, and measurement of all the variables

Source: own study. 


\section{RESULTS AND DISCUSSION}

\section{Frequency Distribution and Descriptive Statistics}

The specification of Ayturk et al. (2017) applies to model credit/sukuk ratings. A credit/sukuk rating score index as a continuous variable is constructed by using the data available from PT. PEFINDO for the Indonesia sample and the data from RAM Rating Services Berhad for the Malaysian sample. The frequency distribution of sukuk ratings for the two samples, Indonesia and Malaysia, is portrayed in detail in Table 2.

Table 3. Descriptive statistics for variables of interest for the Indonesian and Malaysian samples

\begin{tabular}{|c|c|c|c|c|c|c|c|}
\hline \multicolumn{8}{|c|}{ A. The Indonesian Sample } \\
\hline $\begin{array}{l}\text { Items of statistics } \\
\text { descriptive }\end{array}$ & RET & SRAT & $\mathrm{ROI}$ & LEV & IVAL & TBNQ & LN_SIZE \\
\hline Mean & 0.178 & 0.794 & 0.034 & 0.292 & 1492.94 & 1.318 & 23.404 \\
\hline Median & -0.0025 & 0.777 & 0.028 & 0.254 & 665.03 & 1.076 & 23.542 \\
\hline Maximum & 4.994 & 1.00 & 0.204 & 0.795 & 16780.46 & 3.85 & 27.663 \\
\hline Minimum & -0.910 & 0.444 & -0.073 & 0.0008 & -2841.75 & 0.578 & 11.711 \\
\hline Standard Deviation & 0.85 & 0.137 & 0.041 & 0.187 & 2529.92 & 0.668 & 2.230 \\
\hline Observations & 122 & 122 & 122 & 122 & 122 & 122 & 122 \\
\hline \multicolumn{8}{|c|}{ B. The Malaysian Sample } \\
\hline Mean & -0.012 & 0.897 & 0.035 & 0.285 & 5.965 & 1.404 & 16.333 \\
\hline Median & -0.027 & 0.912 & 0.023 & 0.277 & 5.141 & 1.021 & 16.279 \\
\hline Maximum & 0.794 & 1.000 & 0.369 & 0.737 & 51.713 & 9.894 & 20.415 \\
\hline Minimum & -0.779 & 0.050 & -0.193 & 0.000 & -79.782 & 0.635 & 12.944 \\
\hline Standard Deviation & 0.266 & 0.147 & 0.087 & 0.190 & 16.795 & 1.460 & 2.079 \\
\hline Observations & 60 & 60 & 60 & 60 & 60 & 60 & 60 \\
\hline
\end{tabular}

Source: own elaboration of outputs from Eviews 11.

Given Table 3, it appears that some variables (the average ROI, Leverage, and Tobin's Q values) are comparable between the Indonesian and Malaysian samples, but other variables are not (SRAT, IVAL, and Ln_SIZE) as their mean values are significantly different (at the significance level of 0.01). Sukuk ratings in Malaysia look more evenly distributed compared to Indonesia, leading to the highest level of sukuk rating scale. However, when viewed as a whole, the variation in the sukuk ratings values are comparable for either the Indonesian sample or the Malaysian sample, showing a standard-deviation value of 0.137 vs. 0.147 . Unlike the sukuk ratings variable, it appears that stock returns for the Indonesian sample are higher than the ones for the Malaysian sample, i.e. 0.178 vs. 0.012 with a more even distribution for the Malaysian sample (standard deviation $=0.266$ ) compared to Indonesia (standard deviation $=0.85$ ).

\section{Multicollinearity among variables}

Table 4 shows the results of multicollinearity tests among the variables for the two samples, Indonesia and Malaysia. Even though all the variables for the two samples denote the VIF (variance inflation factor) values less than 10 (free from the multicollinearity problem), considering the high cross-correlation between ROI and TBNQ (0.617) (the Indonesian sample), between ROI and IVAL (0.515), and between ROI and TBNQ (0.713) (the Malaysian sample), and also the notion that ROI, IVAL, and TBNQ reflect the same firm-characteristic factor, i.e. firm value (e.g. Haj-Salem et al., 2020), ROI will be excluded in further analysis. 
Table 2. Frequency (Freq.) distribution of sukuk ratings for the Indonesian and Malaysian samples

\begin{tabular}{|c|c|c|c|c|c|c|c|c|c|c|c|c|c|c|c|c|c|}
\hline \multicolumn{18}{|c|}{ A. The Indonesian sample } \\
\hline Column No. & 1 & 2 & 3 & 4 & 5 & 6 & 7 & 8 & 9 & 10 & 11 & 12 & 13 & 14 & 15 & 16 & 17 \\
\hline Sukuk Ratings & idAAA & idAA+ & idAA & idAA- & idA+ & idA & idA- & idBBB+ & idBBB & idBBB- & idBB+ & idBB & idBB- & $\mathrm{idB+}$ & $\begin{array}{l}\text { idB; } \\
\text { idB- }\end{array}$ & $\begin{array}{l}\text { idCCC; } \\
\text { idD }\end{array}$ & TOTAL \\
\hline Sukuk Index & 1 & 0.94 & 0.89 & 0.83 & 0.78 & 0.72 & 0.67 & 0.61 & 0.56 & 0.5 & 0.44 & 0.39 & 0.33 & 0.28 & $\begin{array}{l}0.22 \\
0.17\end{array}$ & $\begin{array}{l}0.11 \\
0.06\end{array}$ & \\
\hline Freq. in 2015 & 13 & 1 & 5 & 8 & 10 & 12 & 6 & 3 & 2 & 1 & 0 & 0 & 0 & 0 & 0 & 0 & 61 \\
\hline Freq. in 2016 & 12 & 1 & 5 & 8 & 10 & 6 & 10 & 6 & 2 & 0 & 1 & 0 & 0 & 0 & 0 & 0 & 61 \\
\hline Total Freq. & 25 & 2 & 10 & 16 & 20 & 18 & 16 & 9 & 4 & 1 & 1 & 0 & 0 & 0 & 0 & 0 & 122 \\
\hline Total Freq. (\%) & 40.98 & 3.3 & 16.39 & 26.2 & 32.8 & 29.5 & 26.2 & 14.75 & 6.56 & 1.64 & 1.64 & 0 & 0 & 0 & 0 & 0 & $100 \%$ \\
\hline
\end{tabular}

\section{B. The Malaysian sample}

\begin{tabular}{|c|c|c|c|c|c|c|c|c|c|c|c|c|c|c|c|c|c|}
\hline Column No. & 1 & 2 & 3 & 4 & 5 & 6 & 7 & 8 & 9 & 10 & 11 & $12^{\S}$ & $13^{\S}$ & $14^{\S}$ & $15^{\S}$ & $16^{\S}$ & 17 \\
\hline Sukuk Ratings & AAA & AA1 & AA2 & AA3 & A1 & $\mathrm{A} 2$ & A3 & $\begin{array}{c}\text { BBB1; BBB2; } \\
\text { BBB3; BB1; } \\
\text { BB2 }\end{array}$ & BB3 & D & $\begin{array}{c}\mathrm{B} 1 ; \mathrm{B} 2 ; \\
\mathrm{B} 3 ; \mathrm{C} 1 ; \mathrm{C} 2 ; \\
\mathrm{C} 3\end{array}$ & $\begin{array}{l}\text { AAA; } \\
\text { AA1 }\end{array}$ & $\begin{array}{l}\text { AA2; } \\
\text { AAA }\end{array}$ & $\begin{array}{l}\text { AA3; } \\
\text { AAA }\end{array}$ & $\begin{array}{c}\text { AA1; } \\
\text { A3; } \\
\text { AA1 } \\
\end{array}$ & $\mathrm{A} 1 ; \mathrm{AA} 2$ & TOTAL \\
\hline Sukuk Index & 1 & 0.95 & 0.9 & 0.85 & 0.8 & 0.75 & 0.7 & $\begin{array}{c}0.65 ; 0.6 ; \\
0.55 ; 0.5 \\
0.45\end{array}$ & 0.4 & 0.05 & $\begin{array}{l}0.35 ; 0.3 ; \\
0.25 ; 0.2 ; \\
0.15 ; 0.1\end{array}$ & 0.975 & 0.95 & 0.925 & 0.866 & 0.85 & \\
\hline Freq. in 2015 & 8 & 5 & 6 & 6 & 1 & 0 & 0 & 0 & 0 & 1 & 0 & 0 & 1 & 1 & 1 & 0 & 30 \\
\hline Freq. in 2016 & 6 & 6 & 7 & 5 & 1 & 1 & 1 & 0 & 1 & 0 & 0 & 1 & 0 & 0 & 0 & 1 & 30 \\
\hline Total Freq. & 14 & 11 & 13 & 11 & 2 & 1 & 1 & 0 & 1 & 1 & 0 & 1 & 1 & 1 & 1 & 1 & 60 \\
\hline Total Freq. (\%) & 23.33 & 18.33 & 21.67 & 18.3 & 3.33 & 1.67 & 1.67 & 0.00 & 1.67 & 1.67 & 0.00 & 1.67 & 1.67 & 1.67 & 1.67 & 1.67 & 100 \\
\hline
\end{tabular}

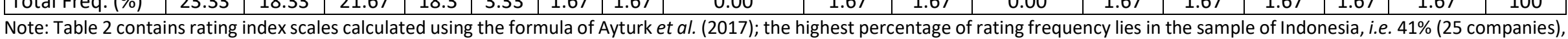
and Malaysia, i.e. $23.33 \%$ (14 companies), while the rest is spread to the lowest index, idBB $+(0.444)$ for the Indonesian sample, and D (0.05) for the Malaysian sample.

$\S$ This score index is the average score index of the combined sukuk-rating scales because of the different sukuk types.

Source: own elaboration of sukuk ratings published by PT. PEFINDO for the Indonesian sample and by RAM Rating Services Berhard for the Malaysian sample. 
Table 4. Multicollinearity among the variables for the Indonesian and Malaysian samples

\begin{tabular}{|c|c|c|c|c|c|c|c|c|}
\hline \multicolumn{9}{|c|}{ A. The Indonesian Sample } \\
\hline Variables & RET & SRAT & ROI & LEV & IVAL & TBNQ & LN_SIZE & VIF \\
\hline RET & 1.000 & 0.0196 & 0.091 & $-0.207^{* *}$ & $0.191 * *$ & $0.357 * * *$ & 0.089 & - \\
\hline SRAT & & 1.000 & 0.169* & $-0.275 * * *$ & $0.187 * *$ & $0.182^{* *}$ & $0.334 * * *$ & 1.35 \\
\hline ROI & & & 1.000 & -0.098 & -0.0072 & $0.617 * * *$ & $-0.355 * * *$ & 2.16 \\
\hline LEV & & & & 1.000 & 0.123 & -0.113 & $-0.190 * *$ & 1.16 \\
\hline IVAL & & & & & 1.000 & 0.078 & 0.146 & 1.09 \\
\hline TBNQ & & & & & & 1.000 & -0.0046 & 1.75 \\
\hline LN_SIZE & & & & & & & 1.000 & 1.56 \\
\hline \multicolumn{9}{|c|}{ B. The Malaysian Sample } \\
\hline RET & 1,000 & $-0,432 * * *$ & 0,145 & 0,038 & 0,151 & $-0,003$ & 0,099 & - \\
\hline SRAT & & 1,000 & $-0,009$ & 0,012 & $-0,009$ & 0,117 & 0,153 & 1.06 \\
\hline ROI & & & 1,000 & $-0,354 * * *$ & $0,515 * * *$ & $0,713^{* * *}$ & $-0,156$ & 5.04 \\
\hline LEV & & & & 1,000 & $-0,476 * * *$ & 0,024 & 0,083 & 1.46 \\
\hline IVAL & & & & & 1,000 & 0,040 & 0,149 & 2.23 \\
\hline TBNQ & & & & & & 1,000 & $-0,093$ & 3.45 \\
\hline LN_SIZE & & & & & & & 1,000 & 1.20 \\
\hline
\end{tabular}

Source: own elaboration of outputs from Eviews 11.

\section{Results of hypotheses testing}

For the Indonesian sample (Table 5), the testing of Hypothesis 1 began directly with applying the two models that include all the independent variables, i.e. SRAT and all the firm-characteristic variables, LEV, IVAL, TBNQ, and ROI (Step 0), by running Model 1 and Model 2. Due to the high cross-correlation between ROI and TBNQ (0.61) and previous literature (Baron, Harjoto, \& Jo, 2011; Siagian, Siregar, \& Rahadian, 2013; Haj-Salem et al., 2020), it appears that ROI and TBNQ reflect the same variable, i.e. firm value, so Model 1 and Model 2 were repeated by excluding ROI (Step 1) either with interactions (Model 2) or without interactions (Model 1). The results showed no significant and positive effect of SRAT on RET in Model 1. When applying the moderated regression analysis (MRA) method (Sharma, Durand, \& Gur-Arie, 1981), the positive and significant coefficient in the SRAT-RET relationship is consistently absent from all the interaction terms included in the model (Model 2). These results suggested that Hypothesis 1 is supported. In Step 2, Model 1 and Model 2 were repeated by excluding TBNQ but, this time, by including leverage and firm-value effects (LEV, IVAL) as seen in Model 1 and Model 2. No positive effect of SRAT on RET appeared as significant. Thus, these results do not support Hypothesis 1. In Step 3, to shed more light on the market value of the firm effect, TBNQ - the most-recommended firm-value variable (see, e.g. Fooladi, Shukor, Saleh, \& Jafar, 2014; Haj-Salem et al., 2020) - was inserted in the model with and without interactions with SRAT, while IVAL was excluded. The results still showed the same conclusion that the SRAT effect on RET is not found to be positively significant. As such, these results are not consistent with Hypothesis 1.

Meanwhile, following the same steps as when testing Hypothesis 1, Hypothesis 2 was tested by looking into the results of Model 2 and referring to the MRA method (Sharma et al., 1981). Model 2 was repeated from Step 0 to Step 3. Step 1 controlled for size effect (In_SIZE), when all the independent variables (excluding ROI) and their interactions with SRAT were included, and only the SRAT-LEV and SRAT-IVAL interactions were found to be positively significant, while the SRAT-TBNQ interaction was negatively significant, as depicted in Model 2 of Step 1 (significant at $p$-value $<0.05$ and marginally significant at $p$-value $<0.10$, respectively). These results suggest that Hypotheses $2 \mathrm{a}$ and $2 \mathrm{~b}$ are supported. In Step 1, Model 2 seemed to be the best because it enjoyed the highest adjusted- $R^{2}$ (adj. $R^{2}$ ) after including all the relevant independent variables but excluding ROI.

In search of consistency, models in Step 1 were repeated in Step 2 by excluding TBNQ, the positive SRAT-LEV and SRAT-IVAL relationship are found to be consistently significant, as depicted in Model 2 of Step 2 (all significant at $p$-value $<0.01$ ), while in Step 3 the model was repeated when two of firm- 
characteristic effects (LEV, TBNQ) were included. The results showed that the positive SRAT-LEV relationship appeared consistently significant while the SRAT-TBNQ relationship denoted its negative significance, as seen in Model 2 of Step 3. These results confirm that LEV and IVAL are the main variables that positively moderate the positive SRAT effect on RET, whereby supporting Hypotheses $2 \mathrm{a}$ and $2 \mathrm{~b}$. The results also show that TBNQ was more consistent in affecting RET as a pure independent variable, while LEV and IVAL better reflected its persistence as pure moderating variables on the relationship between SRAT and RET (see Sharma et al., 1981). Moreover, Ln_SIZE positively and significantly controlled all the tests for size effect, except for Model 1 of Step 0 and Step 1, meaning that size effects significantly and positively accounted for RET.

Table 5. The results of the testing models on Hypotheses $1,2 a$, and $2 b$ for the Indonesian sample

\begin{tabular}{|c|c|c|c|c|c|c|c|c|c|}
\hline \multicolumn{10}{|c|}{ Dependent Variable: RET } \\
\hline $\begin{array}{l}\text { Independent } \\
\text { Variables: }\end{array}$ & Signs & Step 0 & Step 1 & Step 2 & Step 3 & Step 0 & Step $1^{\not h}$ & Step 2 & Step 3 \\
\hline & & Model 1 & Model 1 & Model 1 & Model 1 & Model 2 & Model 2 & Model 2 & Model 2 \\
\hline C & $?$ & 0.628 & 0.271 & $0.666 * * *$ & -0.387 & -0.328 & -1.205 & $1.491 * * *$ & -1.458 \\
\hline SRAT & $+/ ?$ & $-0.779 *$ & $-0.9167 * *$ & $-0.687 * * *$ & $-0.712 * * *$ & -0.026 & 0.237 & $-1.672 * * *$ & 0.300 \\
\hline ROI & $+/ ?$ & -1.995 & & & & 3.172 & & & \\
\hline LEV & $+/ ?$ & $-0.771 * *$ & $-0.717 * *$ & $-0.747 * * *$ & $-0.824 * * *$ & $-2.439 * * *$ & $-2.513 * * *$ & $-3.260 * * *$ & $-3.411^{* * *}$ \\
\hline IVAL & $+/ ?$ & $2.28 \mathrm{E}-05$ & $2.23 \mathrm{E}-05$ & $2.24 \mathrm{E}-5$ & & $-6.79 \mathrm{E}-05$ & $-5.34 \mathrm{E}-05$ & $-5.63 \mathrm{E}-05$ & \\
\hline TBNQ & $+/ ?$ & $0.362^{* * *}$ & $0.288 * * *$ & & $0.429 * * *$ & $1.498 * * *$ & $1.880 * * *$ & & $1.955^{* * *}$ \\
\hline SRAT*ROI & + & & & & & -7.211 & & & \\
\hline SRAT*LEV & + & & & & & $1.753 *$ & $1.928 * *$ & $3.171 * * *$ & $3.315 * * *$ \\
\hline SRAT*IVAL & + & & & & & $0.00014^{* *}$ & $0.00013 *$ & $\begin{array}{l}7.77 \mathrm{E}- \\
05^{* * *}\end{array}$ & \\
\hline SRAT*TBNQ & + & & & & & $-1.168 * * *$ & $-1.749 * * *$ & & $-1.831 * * *$ \\
\hline Ln_SIZE & $?$ & -0.0022 & 0.018 & $0.010 * * *$ & $0.034 * *$ & $0.005^{* * *}$ & $0.034 * * *$ & $0.010 * * *$ & $0.043 * *$ \\
\hline $\mathrm{R}^{2}$ & & 0.234 & 0.271 & 0.144 & 0.235 & 0.297 & 0.288 & 0.168 & 0.259 \\
\hline Adj. $R^{2}$ & & 0.187 & 0.1876 & 0.107 & 0.202 & 0.226 & 0.231 & 0.117 & 0.214 \\
\hline F-statistic (stat.) & & 4.943 & 5.658 & 3.910 & 7.123 & 4.181 & 5.034 & 3.288 & 5.709 \\
\hline$p$-value & & 0.000 & 0.000 & 0.002 & 0.000 & 0.000 & 0.000 & 0.003 & 0.000 \\
\hline Pooled-OLS & & No & No & No & No & No & No & No & No \\
\hline Fixed-effect & & Yes ${ }^{\bullet}$ & Yes & Yes ${ }^{\bullet}$ & Yes & Yes & Yes & Yes & Yes \\
\hline Random-effect & & No & No & No & No & No & No & No & No \\
\hline $\begin{array}{l}\text { F-stat. (Chow } \\
\text { test) } \\
\text { ( } p \text {-value) }\end{array}$ & & $\begin{array}{c}10.587 \\
(0.0015)\end{array}$ & $\begin{array}{c}11.44 \\
0.001)\end{array}$ & $\begin{array}{c}11.349 \\
(0.0010)\end{array}$ & $\begin{array}{c}10.051 \\
(0.0019)\end{array}$ & $\begin{array}{c}9.084 \\
(0.0032)\end{array}$ & $\begin{array}{c}10.285 \\
(0.0017)\end{array}$ & $\begin{array}{c}11.749 \\
(0.0008)\end{array}$ & $\begin{array}{c}10.739 \\
(0.0014)\end{array}$ \\
\hline $\begin{array}{l}\text { LM-statistic } \\
\text { ( } p \text {-value) }\end{array}$ & & $\begin{array}{c}0.01 \\
(0.4541)\end{array}$ & $\begin{array}{c}0.02 \\
(0.4444)\end{array}$ & $\begin{array}{c}0 \\
(1)\end{array}$ & $\begin{array}{c}0.11 \\
(0.3713)\end{array}$ & $\begin{array}{c}0.02 \\
(0.4472)\end{array}$ & $\begin{array}{c}0.02 \\
(0.4492)\end{array}$ & $\begin{array}{c}0 \\
(1)\end{array}$ & $\begin{array}{c}0.05 \\
(0.4130)\end{array}$ \\
\hline Observations & & $\begin{array}{c}122 \\
(61 \times 2)\end{array}$ & $\begin{array}{c}122 \\
(61 \times 2)\end{array}$ & $\begin{array}{c}122 \\
(61 \times 2)\end{array}$ & $\begin{array}{c}122 \\
(61 \times 2)\end{array}$ & $\begin{array}{c}122 \\
(61 \times 2)\end{array}$ & $\begin{array}{c}122 \\
(61 \times 2)\end{array}$ & $\begin{array}{c}122 \\
(61 \times 2)\end{array}$ & $\begin{array}{c}122 \\
(61 \times 2)\end{array}$ \\
\hline
\end{tabular}

Note: ${ }^{\circ}$ Considering the Chow tests (all $p$-values are lower than 0.05 ) and LM (Breusch and Pagan Lagrangian multiplier) tests (all $p$-values are higher than 0.05), the fixed-effect models were applied; thus, Hausman test is not relevant. '+/?' indicates the two predicted signs among the models: the predicted sign of ' + ' stands for a non-interaction model (without moderating effects), while the predicted sign of '?' that may appear as various signs because of the pure-or-quasi-moderator assumption (Sharma et al., 1981) stands for a model with the moderating effects.

II $\mathrm{t}$ is the best model since it enjoys the highest adj. $\mathrm{R}^{2}$, after including all the relevant independent variables, but excluding ROI. $*, * *, * * *$ refers to $10 \%, 5 \%$, and $1 \%$ levels of significance respectively.

Source: own study. 
For the Malaysian sample (Table 6), Hypothesis 1 was tested by following only two steps, preceded by Step 0. Furthermore, the MRA analysis was adopted to arrive at a consistent inference. From the results of Step 0 in Model 1, all ROI effects were significant, but due to the existence of a high cross-correlation between ROI and TBNQ (0.71) and between ROI and IVAL (0.51) - with insights from the measurement of ROI and TBNQ reflecting the same firm-value variable from Baron et al. (2011), Siagian et al. (2013), and Haj-Salem et al. (2020) - Model 1 and Model 2 were repeated from Step 0 . The two models incorporated all the independent variables, i.e. SRAT, and all the firmcharacteristic variables, i.e. LEV, IVAL, and TBNQ (excluding ROI), either with or without their interactions. The two models in Step 1 suggest that when effects of the three variables, LEV, IVAL, and TBNQ, were included to serve as pure independent variables, the positive effect of SRAT on RET was not found to be significant, as indicated in Model 1, but when they were included in the model to appear as both independent and moderating variables on the SRAT-RET relationship, the positive effect of SRAT on RET was found to be consistently significant at the significance level of $p$ value $<0.01$, as seen in Model 2.

Next, when TBNQ was inserted in the model with IVAL excluded due to all of its non-significant effects on the IVAL-RET relationship in Step 1 of Model 1 and Model 2, the result did not show significant and positive coefficients; that is, the positive effect of SRAT on RET was not found to be significant. Meanwhile, the positive effect of SRAT on RET was found to be consistently significant in Model 2 of Step 2 when TBNQ and interaction terms were included but IVAL was excluded. These results confirm that Hypothesis 1 is supported when controlling for size effect and considering the effects of leverage, firm value (TBNQ), and their interaction terms.

Meanwhile, to test Hypotheses $2 a$ and $2 b$, the study focused only on Model 2, following the same steps as when testing Hypothesis 1 . Analysis was conducted but only on moderating effects of firm-characteristic variables (excluding ROI) on the SRAT-RET relationship (with the MRA method). In Step 1, by excluding ROI (in Step 0), the results suggested that the significant and positive effects of LEV, IVAL, and TBNQ did not exist to moderate the positive SRAT-RET relationship. Likewise, when IVAL was excluded and replaced by TBNQ to proxy for firm-value, the results were still inconsistent with the expected hypothesis. Hence, the significant and positive effects of LEV and TBNQ were not found to moderate the positive SRAT-RET relationship, as seen in Model 2 of Step 2. In this step, Model 2 shows the best model because its highest adj. $R^{2}$ was obtained after including all the relevant independent variables but excluding ROI. These results suggest that $\mathrm{Hy}-$ potheses $2 \mathrm{a}$ and $2 \mathrm{~b}$ are not supported. In this regard, the positive Ln_SIZE effect on RET was also significantly found to control for size effects in all the tests, suggesting that RET was also significantly and positively accounted for by size effects. 
Table 6. The results of the testing models on hypotheses $1,2 a$, and $2 \mathrm{~b}$ for the Malaysian sample

\begin{tabular}{|c|c|c|c|c|c|c|c|}
\hline \multicolumn{8}{|c|}{ Dependent Variable: RET } \\
\hline $\begin{array}{l}\text { Independent } \\
\text { Variables: }\end{array}$ & Signs & Step 0 & Step 1 & Step 2 & Step 0 & Step 1 & Step $2^{\text {th }}$ \\
\hline & & Model 1 & Model 1 & Model 1 & Model 2 & Model 2 & Model 2 \\
\hline C & - & $-20.601 * * *$ & $-14.558^{* * *}$ & $-13.623 * * *$ & $-1.320 * * *$ & $-34.286 * * *$ & $-19.274 * * *$ \\
\hline SRAT & $+/ ?$ & $-0.303 * * *$ & -0.082 & 0.003 & $0.776^{*}$ & $12.525^{* * *}$ & $8.488 * * *$ \\
\hline ROI & $+/ ?$ & $2.964 * * *$ & & & $7.167 * *$ & & \\
\hline LEV & $+/ ?$ & $1.859 * * *$ & $1.131^{* * *}$ & $1.008^{* *}$ & $2.126 * *$ & $19.650 * * *$ & $11.814^{* * *}$ \\
\hline IVAL & $+/ ?$ & $-0.009 * * *$ & -0.0004 & & $-0.049 * * *$ & 0.028 & \\
\hline TBNQ & $+/ ?$ & $0.265 * * *$ & $0.358 * * *$ & $0.358 * * *$ & $0.735^{* * *}$ & $3.764 * * *$ & $3.217 * * *$ \\
\hline SRAT*ROI & + & & & & $-6.437^{*}$ & & \\
\hline SRAT*LEV & + & & & & $-2.081^{*}$ & $-19.922 * * *$ & $-11.940 * * *$ \\
\hline SRAT*IVAL & + & & & & $0.052 * * *$ & -0.037 & \\
\hline SRAT*TBNQ & + & & & & $-0.765 * * *$ & $-3.681^{* * *}$ & $-3.174 * * *$ \\
\hline Ln_SIZE & $?$ & $1.219 * * *$ & $0.844^{* * *}$ & $0.785 * * *$ & $0.027^{* * *}$ & $1.347 * * *$ & $0.667 * * *$ \\
\hline$R^{2}$ & & 0.976 & 0.957 & 0.947 & 0.625 & 0.989 & 0.9969 \\
\hline Adj. $R^{2}$ & & 0.941 & 0.898 & 0.879 & 0.549 & 0.973 & 0.9925 \\
\hline F-stat. & & 28.124 & 16.436 & 14.029 & 8.179 & 58.657 & 2252.74 \\
\hline$p$-value & & 0.000 & 0.000 & 0.000 & 0.000 & 0.000 & 0.000 \\
\hline Pooled-OLS & & No & No & No & Yes & No & No \\
\hline Fixed-effect & & Yes & Yes & Yes & No & Yes & Yes \\
\hline Random effect & & No & No & No & No & No & No \\
\hline $\begin{array}{l}\text { F-stat. (Chow } \\
\text { test) } \\
\text { ( } p \text {-value) } \\
\end{array}$ & & $\begin{array}{l}11.865 \\
(0.000)\end{array}$ & $\begin{array}{c}8.438 \\
(0.000)\end{array}$ & $\begin{array}{c}8.411 \\
(0.000)\end{array}$ & $\begin{array}{c}0.651 \\
(0.424)\end{array}$ & $\begin{array}{l}17.972 \\
(0.000)\end{array}$ & $\begin{array}{c}70.775 \\
(0.0000)\end{array}$ \\
\hline $\begin{array}{l}\text { LM-statistic } \\
(p \text {-value })\end{array}$ & & $\begin{array}{c}0.62 \\
(0.215) \\
\end{array}$ & $\begin{array}{c}0.28 \\
(0.299)\end{array}$ & $\begin{array}{c}0.00 \\
(0.478)\end{array}$ & $\begin{array}{c}0.37 \\
(0.272) \\
\end{array}$ & $\begin{array}{c}0.09 \\
(0.384)\end{array}$ & $\begin{array}{c}0.02 \\
(0.445) \\
\end{array}$ \\
\hline Observations & & $60(30 \times 2)$ & $60(30 \times 2)$ & $60(30 \times 2)$ & $60(30 \times 2)$ & $60(30 \times 2)$ & $60(30 \times 2)$ \\
\hline
\end{tabular}

Note: ${ }^{-}$Considering the Chow tests (all $p$-values are lower than 0.05) and LM (Breusch and Pagan Lagrangian multiplier) tests (all $p$-values are higher than 0.05), the fixed-effect models were applied, except for Model 2 in Step 0 ( $p$-value of the Chow test is 0.424 , higher than 0.05 , a pooled-OLS model is preferred). In this regard, the Hausman test is not relevant. '+/?' indicates the two predicted signs among the models: the predicted sign of ' + ' stands for a non-interaction model (without moderating effects), while the predicted sign of '?' that may appear as various signs because of the pure-or-quasi moderator assumption (Sharma et al., 1981) stands for a model with the moderating effects.

It is the best model since it enjoys the highest adj. $\mathrm{R}^{2}$, after including all the relevant independent variables but excluding $\mathrm{ROI}$.

$*, * *, * * *$ refers to $10 \%, 5 \%$, and $1 \%$ levels of significance respectively.

Source: own study.

\section{CONCLUSIONS}

When controlling for size effect and considering some firm-characteristic effects, all the results from the Malaysian sample convincingly support Hypothesis 1 rather than Hypotheses $2 a$ and $2 b$. Thus, Malaysian investors place more emphasis on their sukuk ratings than the Indonesian investors, who base their business strategy on aggregate insights from both their sukuk ratings and firm-characteristic metrics, i.e. especially the level of leverage and firm (intrinsic) value. In other words, when controlling for size effect, the moderating effects of LEV and IVAL are found to be positively significant on the sukuk ratings-stock return relationship in the Indonesian sample, thereby supporting Hypotheses $2 \mathrm{a}$ and $2 \mathrm{~b}$. Thus, these results illustrate that when valuing stock (stock returns) in Indonesia, the interactions between sukuk ratings and leverage and also between sukuk ratings and firm value (IVAL) - which reflect a firm's fundamental value - is more pervasive among investors' investment activities. Meanwhile, a firm's value reflecting a market-based firm-value indicator (TBNQ) is more commonly found to serve as a pure independent variable that affects stock returns positively. 
Therefore, we may conclude that - in some cases - sukuk ratings have a positive and direct effect on stock returns, which is consistent with the findings of $\mathrm{Ng}$ and Ariff (2019), Khartabiel et al. (2020), Mohamed et al. (2017), Rahim and Ahmad (2016), and Ab Hamid et al. (2014). However, utilizing sukuk ratings to determine the stock price (stock return) in other cases, is to some extent not direct and constant but, instead, contingent on and involving other variables, i.e. firm-characteristic variables. This certainly supports the abovementioned statement from Moody's, one of the big three rating agencies in the world, that many factors are involved in the judgement of the quality of long-term credit, including sukuk (Moody's Credit Ratings \& Research, Moody's Investors Service, 1995). One reason why these sukuk rating effects on stock returns look to be different could be attributed to the fact that the types of other specific variables involved in examining the sukuk rating effect on stock returns may vary depending on the comparative characteristics of the sampled countries.

In some respects, Malaysia has statistically enjoyed better macroeconomic indicators than Indonesia. In the last three years (2017-2019), the average GDP per capita for Malaysia was higher than in Indonesia: 28 937.43 USD for Malaysia vs 12113.88 USD for Indonesia (The World Bank, 2020). Besides, in 2018-2020 the default-risk profile for Malaysia was also better than for Indonesia, indicated by their comparative credit rating values: A3 for Malaysia vs Baa2 for Indonesia (Moody's Rating), A- vs BBB (S\&P Rating), and A- vs BBB (Fitch Rating). Specifically, the global sukuk market share for Malaysia is also much greater than Indonesia, i.e. $60.84 \%$ vs $7.225 \%$ of the global sukuk market share. Thus, Malaysia is the world leader in sukuk (IIFM, 2019). Moreover, sukuk is regarded in Malaysia as an instrument that is not riskier than conventional bonds; the risk profile of sukuk (measured by value-at-risk or VaR) is evidently in line with credit rating predictions (Alam, Bhatti, \& Wong, 2018).

Given all the above comparative performance of these country-specific characteristics (macroeconomy, risk-default, and sukuk market share profile), Malaysia seems to place at a relatively more advanced level of sukuk ratings than Indonesia. Thus, sukuk ratings in Malaysia attract much more interest and trust from many investors than sukuk ratings in Indonesia. Furthermore, the comparability of risk between sukuk and conventional bonds, along with consistency between sukuk-risk profile and credit-rating predictions in Malaysia (Alam, Bhatti, \& Wong, 2018), could be another plausible explanation. The above explanations lead us to confirm one reason why the assessment of sukuk by sukuk rating agencies has a direct effect on stock returns and is more pronounced in Malaysia than in Indonesia. Therefore, sukuk ratings tend to better serve as the key determinant in pricing stock (stock returns) in Malaysia than in Indonesia, in which they are relatively less accounted for by its investors but, instead, their role seems to be contingent on some firm-characteristic variables (LEV and IVAL).

When testing the hypotheses, the study conducted some robustness checks. First, the models were tested by excluding the control variable (In_SIZE) to make sure that there appears the effect of the control variable. To the best of my testing abilities, most of the control variable effects in all the models appear to be significant. Thus, all the above results are reported by controlling for size effect (In_SIZE). Besides, a conjecture of a simultaneity bias and reverse causation regarding stock returns also impacts sukuk ratings, which has been checked by applying the Durbin-Wu-Hausman (DWH) test. All the samples show that reverse causation does not exist. The null hypothesis that there is no simultaneity correlation failed to be rejected ( $p$-value $=0.18>0.10$ and $p$-value of 0.4149 , higher than a $10 \%$ level of significance, for the Indonesian and Malaysian sample respectively).

However, some limitations remain and require much attention from future studies, e.g. the data is still limited, especially from Malaysia. To receive better insights of a country's characteristic effect, coverage could be increased from a limited number of countries (Indonesia and Malaysia) to more countries, especially Muslim or non-Muslim sukuk-issuing countries. Moreover, moderating variables could involve not only some firm-characteristic variables or a company-level analysis but also a wider level of analysis, such as an industry-level or country-level analysis. The use of sukuk-rating data from credible credit-rating agencies is also highly recommended, given the significance credit-rating reputation (Baghai, Servaes, \& Tamayo, 2014; Bedendo, Cathcart, \& El-Jahel, 2018). 


\section{REFERENCES}

Ab Hamid, N.H., Zakaria, N.B., \& Ab Aziz, N.H. (2014). Firms' performance and risk with the presence of sukuk rating as default risk, Procedia - Social and Behavioral Sciences, 145, 181 - 188. https://doi.org/10.1016/j.sbspro.2014.06.025

Abd Rahim, S., \& Ahmad, N. (2016). Investigating FTSE KLCl using CAAR estimations following sukuk announcement in Malaysia: Based on sukuk ratings. Journal of Investment and Management, 5(6), 158-165. https://doi.org/ 10.11648/j.jim.20160506.19

Aguinis, H., Edwards, J.R., \& Bradley, K.J. (2016). Improving our understanding of moderation and mediation in strategic management research. Organizational Research Methods, 20(4), 665-685. https://doi.org/10.1177/1094428115627498

Ahmad, N., Daud, S.N., \& Kefeli, Z. (2012). Economic forces and the sukuk market. Procedia: Social and Behavioral Sciences, 65, 127-133. https://doi.org/10.1016/j.sbspro.2012.11.101

Ahmed, H., \& Elsayed, A. (2019). Are Islamic and conventional capital markets decoupled? Evidence from stock and bonds/sukuk markets in Malaysia. The Quarterly Review of Economics and Finance, 74, 56-66. https://doi.org/10.1016/j.qref.2018.04.005

Alam, N., Bhatti, M., \& Wong, J.T.F. (2018). Assessing sukuk defaults using value-at-risk techniques. Managerial Finance, 44(6), 665-687. https://doi.org/10.1108/MF-05-2018-0218

Alam, N., Hassan, M.K., \& Haque, M.A. (2013). Are Islamic bonds different from conventional bonds? International evidence from capital market tests. Borsa Istanbul Review, 13(3), 22-29. https://doi.org/10.1016/j.bir.2013.10.006

Alaoui, A., Dewandaru, G., Rosly, S., \& Masih, M. (2015). Linkages and co-movement between international stock market returns: Case of Dow Jones Islamic Dubai financial market index. Journal of International Financial Markets, Institutions and Money, 36, 53-70. https://doi.org/10.1016/j.intfin.2014.12.004

Aloui, C., Hammoudeh, S., \& Hamida, H. (2015a). Co-movement between sharia stocks and sukuk in the GCC markets: A time-frequency analysis. Journal of International Financial Markets, Institutions and Money, 34, 69-79. https://doi.org/10.1016/j.intfin.2014.11.003

Aloui, C., Hammoudeh, S., \& Hamida, H. (2015b). Global factors driving structural changes in the co-movement between sharia stocks and sukuk in the Gulf Cooperation Council countries. The North American Journal of Economics and Finance, 31, 311-329. https://doi.org/10.1016/j.najef.2014.12.002

Aloui, C., Hammoudeh, S., \& Hamida, H. (2015c). Price discovery and regime shift behavior in the relationship between sharia stocks and sukuk: A two-state markov switching analysis. Pacific-Basin Finance Journal, 34, 121-135. https://doi.org/10.1016/j.najef.2014.12.002

Akhtar, S., Akhtar, F., Jahromi, M., \& John, K. (2017). Impact of interest rate surprises on Islamic and conventional stocks and bonds. Journal of International Money and Finance, 79, 218-231. https://doi.org/10.1016/j.jimonfin.2017.09.003

Ariff, M., \& Safari, M. (2015). Valuation of Islamic debt instruments, the Sukuk: Lessons for market development. In H.A. El-Karanshawy et al. (Eds.). Islamic banking and finance-Essays on corporate finance, efficiency, and product development (pp. 1-17). Doha, Qatar: Bloomsbury Qatar Foundation. Retrieved from http://www.wijdantariq.com/wp-content/uploads/2016/05/Islamic-Finance-Book_Volume_3.pdf\#page=18 on September 30, 2020.

Arundina, T., Omar, M.A., \& Kartiwi, M. (2015). The predictive accuracy of sukuk ratings: Multinomial logistic and neural network inferences. Pacific-Basin Finance Journal, 34, 273-292. https://doi.org/10.1016/j.pacfin.2015.03.002

Asutay, M., \& Hakim, A. (2018). Exploring international economic integration through sukuk market connectivity: A network perspective. Research in International Business and Finance, 46, 77-94. https://doi.org/10.1016/j.ribaf.2017.10.003

Ayturk, Y., Asutay, M., \& Aksak, E. (2017). What explains corporate sukuk primary market spreads?. Research in International Business and Finance, 40, 141-149. https://doi.org/10.1016/j.ribaf.2017.01.002

Azmat, S., Skully, M., \& Brown, K. (2014). Issuer's choice of Islamic bond type. Pacific-Basin Finance Journal, 28, 122-135. https://doi.org/10.1016/j.pacfin.2013.08.008 
Baghai, R.P., Servaes, H., \& Tamayo, A. (2014). Have rating agencies become more conservative? Implications for capital structure and debt pricing. Journal of Finance, 69(5), 1961-2005. https://doi.org/10.1111/jofi.12153

Baron, D.P., Harjoto, M.A., \& Jo, H. (2011). The economics and politics of corporate social performance. Business and Politics, 13(02), 1-46. https://doi.org/10.2202/1469-3569.1374

Bedendo, M., Cathcart, L., \& El-Jahel, L. (2018). Reputational shocks and the information content of credit ratings. Journal of Financial Stability, 34, 44-60. https://doi:10.1016/j.jfs.2017.12.003

Bhatti, M.I. (2007). Sukuk and the bonding of Islamic finance. Monash Business Review, 3(1), 17-18. https://doi.org/10.2104/mbr07004

Blume, M.E., Lim, F., \& Mackinlay, A.C. (1998). The declining quality of US corporate debt: Myth or reality?. The Journal of Finance, 53(4), 1389-1413. Retrieved from http://www.jstor.org/stable/117406 on September 30, 2020.

Dang, C., (Frank) Li, Z., \& Yang, C. (2018). Measuring firm size in empirical corporate finance. Journal of Banking \& Finance, 86, 159-176. https://doi.org/10.1016/j.jbankfin.2017.09.006

Elhaj, M.A.A., Muhamed, N.A., \& Ramli, N.M. (2015). The influence of corporate governance, financial ratios, and sukuk structure on sukuk rating. Procedia Economics and Finance, 31, 62-74. https://doi.org/10.1016/s22125671(15)01132-6

Fauzi, F., Foo, D., \& Basyith, A. (2017). Islamic bond announcement: Is there any effect on returns?. Global Business Review, 18, 1-21. https://doi.org/10.1177/0972150916668602

Fooladi, M., Shukor, Z.A., Saleh, N.M., \& Jaffar, R. (2014). The effect of corporate governance and divergence between cash flow and control rights on firm performance. International Journal of Disclosure and Governance, 11(4), 326-340. https://doi.org/10.1057/jdg.2013.24

Godlewski, C., Turk-Ariss, R., \& Weill, L. (2013). Sukuk vs. conventional bonds: A stock market perspective. Journal of Comparative Economics, 41, 745-761. https://doi.org/10.1016/j.jce.2013.02.006

Godlewski, C.J., Turk-Ariss, R., \& Weill, L. (2010). Are sukuk really special? Evidence from the Malaysian Stock Exchange. BOFIT Discussion Papers, 6/2011, Helsinki: Bank of Finland. Retrieved from https://www.academia.edu/1209825/Are_Sukuk_Really_Special_Evidence_from_the_Malaysian_Stock_Exchange on September 30, 2020.

Grier, P., \& Katz, S. (1976). The differential effects of bond rating changes among industrial and public utility bonds by maturity, The Journal of Business, 49(2), 226-39. https://doi.org/10.1086/295833

Haj-Salem, I., Damak Ayadi, S., \& Hussainey, K. (2020). The joint effect of corporate risk disclosure and corporate governance on firm value. International Journal of Disclosure and Governance, 17, 123-140. https://doi.org/10.1057/s41310-020-00079-w

Hand, J.R.M., Holthausen, R.W., \& Leftwich, R.W. (1992). The effect of bond rating agency announcements on bond and stock prices. Journal of Finance, 47(2), 733-52. https://doi.org/10.2307/2329121

Hassan, M., Aliyu, S., Paltrinieri, A., \& Khan, A. (2019). A review of Islamic investment literature. Economic Papers, 38(4), 345-380. https://doi.org/10.1111/1759-3441.12230

Hassan, M.K., Paltrinieri, A., Dreassi, A., Miani, S., \& Sclip, A. (2018). The determinants of co-movement dynamics between sukuk and conventional bonds. The Quarterly Review of Economics and Finance, 68, 73-84. https://doi.org/10.1016/j.qref.2017.09.003

International Islamic Financial Market (IIFM). (2019). Sukuk Report: Comprehensive Study of the Global Sukuk Market, 8th Edition (July). Retrieved from https://www.iifm.net/wp-content/uploads/2019/08/IIFM-SukukReport-8th-Edition_4.pdf on June 25, 2020.

Khartabiel, G., Abu-Alkheil, A., Tunku Ahmad, T.S., \& Khan, W. (2020). Shari'ah-compliant Sukuk versus conventional bond announcements: Is there a wealth effect?. Review of Quantitative Finance, \& Accounting 54, 1059-1073. https://doi: 10.1007/s11156-019-00799-3

Klein, P.-O., Turk, R., \& Weill, L. (2017). Religiosity vs. well-being effects on investor behavior. Journal of Economic Behavior \& Organization, 138, 50-62. https://doi.org/10.1016/j.jebo.2017.04.009

Kordvani, A. (2009). A legal analysis of the Islamic bonds in Iran. International Journal of Islamic and Middle Eastern Finance and Management, 2(4), 323-337. https://doi.org/10.1108/17538390911006377

Lin, J., \& Sung, J. (2014). Assessing the Graham's formula for stock selection: Too good to be true?. Open Journal of Social Sciences, 2(1-5). https://doi.org/10.4236/jss.2014.23001 
Mohamed, M., Yahya, N.C., \& Ishak, N.A. (2017). Market reactions towards the announcement of sukuk issuance: Evidence from Malaysian Market. Jurnal Pengurusan 49, 89-102. https://doi.org/10.17576/pengurusan2017-49-08

Moody's Investors Service. (1995). Moody's Credit Ratings and Research.

Murcia, F.C.d.S, Murcia, F.D.R., Rover, S., \& Borba, J.A. (2014). The determinants of credit rating: Brazilian evidence. Brazilian Administration Review, 11(2), 188-209. https://doi.org/10.1590/S1807-76922014000200005

Naifar, N., \& Hammoudeh, S. (2016). Do global financial distress and uncertainties impact GCC and global sukuk return dynamics?. Pacific-Basin Finance Journal, 39, 57-69. https://doi.org/10.1016/j.pacfin.2016.05.016

Naifar, N., Hammoudeh, S., \& Al dohaimanae, M. (2016). Dependence structure between sukuk (Islamic bonds) and stock market conditions: An empirical analysis with Archimedean copulas. Journal of International Financial Markets, Institutions and Money, 44, 148-165. https://doi.org/10.1016/j.intfin.2016.05.003

Nagano, M. (2017). Sukuk issuance and information asymmetry: Why do firms issue sukuk?. Pacific-Basin Finance Journal, 42, 142-157. https://doi.org/10.1016/j.pacfin.2016.12.005

$\mathrm{Ng}$, A., \& Ariff, M. (2019). Does credit rating revision affect the price of a special class of common stock?. Borsa Istanbul Review. 19-S1, S44-S55. https://doi.org/10.1016/j.bir.2019.02.004

Paltrinieri, A., Hassan, M.K., Bahoo, S., \& Khan, A. (2019). A bibliometric review of sukuk literature. International Review of Economics \& Finance. https://doi.org/10.1016/j.iref.2019.04.004

Qizam, I., \& Fong, M. (2019). Developing financial disclosure quality in sukuk and bond market: Evidence from Indonesia, Malaysia, and Australia. Borsa Istanbul Review, 19(3), 228-248, 2019. https://doi.org/10.1016/j.bir.2019.05.002

Rohim, M., \& Shereeza, M.S. (2013). Analysis on the thoughts of Imam Abu Hanifah and Imam Syafi'i on the ljtihad method for sukuk instrument. Jurnal Teknologi, 62(1), 17-24. https://doi.org/10.11113/jt.v62.1205

Said, A., \& Grassa, R. (2013). The determinants of sukuk market development: Does macroeconomic factors influence the construction of certain structure of Sukuk?. Journal of Applied Finance and Banking, 3(5), 251-267. Retrieved from https://www.scienpress.com/journal_focus.asp?main_id=56\&Sub_id=IV\&Issue $=844$ on July 10, 2020.

Sclip, A., Dreassi, A., Miani, S., \& Paltrinieri, A. (2016). Dynamic correlations and volatility linkages between stocks and sukuk. Review of Financial Economics, 31, 34-44. https://doi.org/10.1016/j.rfe.2016.06.005

Shafron, E. (2019). Investor tastes: Implications for pricing in the public debt market. Journal of Corporate Finance, 55, 6-27. https://doi.org/10.1016/j.jcorpfin.2018.08.006

Sharma, S., Durand, R.M., \& Gur-Arie, O. (1981). Identification and analysis of moderator variables. Journal of Marketing Research, 18(3), 291. https://doi.org/10.2307/3150970

Siagian, F., Siregar, S.V., \& Rahadian, Y. (2013). Corporate governance, reporting quality, and firm value: Evidence from Indonesia. Journal of Accounting in Emerging Economies, 3(1), 4-20. https://doi.org/10.1108/20440831311287673

Smaoui, H., \& Khawaja, M. (2017). The determinants of sukuk market development. Emerging Markets Finance and Trade, 53(7), 1501-1518. https://doi.org/10.1080/1540496X.2016.1224175

Smaoui, H., Mimouni, K., \& Temimi, A. (2019). The impact of sukuk on the insolvency risk of conventional and Islamic banks. Applied Economics, 52(8), 806-824. https://doi.org/10.1080/00036846.2019.1646406

Smaoui, H., \& Nechi, S. (2017). Does sukuk market development spur economic growth?. Research in International Business and Finance, 41(October), 136-147. https://doi.org/10.1016/j.ribaf.2017.04.018

Usmani, T. (2008). Sukuk and their contemporary applications. Retrieved from http://Sukuk.net/library/education/MuftiTaqiSukukpaper.pdf. on June 23, 2020.

The World Bank. (2020). Indicators: GDP per Capita. Retrieved from https://data.worldbank.org/indicator/ on June 23, 2020.Wu, A.D., \& Zumbo, B.D. (2007). Understanding and using mediators and moderators. Social Indicators Research, 87(3), 367-392. https://doi.org/10.1007/s11205-007-9143-1

Zulkhibri, M. (2015). A synthesis of theoretical and empirical research on sukuk. Borsa Istanbul Review, 15(4), 237-248. https://doi.org/10.1016/j.bir.2015.10.001 


\section{Author}

\section{Ibnu Qizam}

The author holds a Doctorate in Accounting from Gadjah Mada University, Yogyakarta, Indonesia, and is Associate Professor in Accounting at the Faculty of Economics and Business, Universitas Islam Negeri (UIN) Syarif Hidayatullah Jakarta, Indonesia. His research interests include market-based accounting, corporate finance, Islamic finance, and corporate governance.

Correspondence to: Ibnu Qizam, Dr., Faculty of Economics and Business, UIN Syarif Hidayatullah Jakarta, Jl. Ibnu Sina IV, Ciputat, Tangerang Selatan, Banten, Indonesia, 15412; e-mail: qzami68@gmail.com ORCID (1) http://orcid.org/0000-0003-4881-3118

\section{Acknowledgements and Financial Disclosure}

I thank the anonymous referees, and also my colleagues at the Faculty of Economics and Business, Universitas Islam Negeri (UIN) Syarif Hidayatullah Jakarta, Indonesia for their constructive comments and suggestions.

\section{Conflict of Interest}

The author declares that the research was conducted in the absence of any commercial or financial relationships that could be construed as a potential conflict of interest.

\section{Copyright and License}

This article is published under the terms of the Creative Commons Attribution - NoDerivs (CC BY-ND 4.0) License http://creativecommons.org/licenses/by-nd/4.0/ 
